\title{
The recognition of Hageman deficiency in blood donors
}

\author{
W. L. MARSH AND W. J. JENKINS \\ From the North-East Metropolitan Regional Blood Transfusion Centre, Brentwood, Essex
}

SYNOPSIS The laboratory findings on a blood donor whose blood coagulation time was greatly prolonged are described. The defect was caused by a deficiency of Hageman (contact) factor, the nature of the defect being demonstrated by a simple glass adsorption test using normal serum.

Abnormally prolonged coagulation of human blood in vitro due to a deficiency of Hageman factor was first described by Ratnoff and Colopy (1955). It is a rare familial trait, known to affect both sexes, but is not associated with a haemorrhagic tendency in vivo. Margolis (1957), Biggs, Sharp, Margolis, Hardisty, Stewart, and Davidson (1958), and Soulier, Wartelle, and Ménaché (1958) have contributed to our understanding of the part played by Hageman factor in the activation of the coagulation mechanism. It is believed by the above workers that Hageman factor is normally present in the inactive phase in plasma, but is itself activated by contact with glass after which it reacts with plasma thromboplastin antecedent, thus initiating further stages of thromboplastin generation.

The importance of recognizing Hageman factor deficiency lies in its differentiation from other coagulation disorders during the performance of tests in vitro.

In a deficiency which produces no clinical abnormality, a true picture of its incidence is more likely to emerge from an investigation of the normal population. The National Blood Transfusion Service regularly collects blood samples from many thousands of normal volunteers and occasional cases of Hageman deficiency may be encountered. Although the abnormality would pass unnoticed in the bottle containing anticoagulant, it is the practice to take a clotted blood sample from each donor for laboratory tests and it is on this sample that the defect may be recognized. It is the purpose of this report to describe such a finding and to detail a simple test by which the nature of the defect may be demonstrated.

Received for publication 6 March 1961.

\section{CASE REPORT}

A blood donor, Miss S., aged 19 years, had given two donations without any abnormal findings. On the third occasion it was found that 24 hours after the donation only a trace of fibrin clot was present in the laboratory sample. An attempt to remove 'serum' with a pasteur pipette was followed five minutes later by the formation of a firm clot throughout the whole specimen. A recalcified plasma clotting time, made with the plasma from the main donation, was grossly prolonged and Miss S. was recalled a few days later for further investigation. The donor stated that she had suffered severe haemorrhage following tonsillectomy six years ago and that she tended to ooze blood for a few days after extraction of a tooth. At no time, however, had any haemorrhage necessitated a blood transfusion. She appeared fit and well. There was no family history of bleeding tendencies.

\section{LABORATORY RESULTS}

Bleeding time (Duke's method)......... min. $30 \mathrm{sec}$.

Coagulation time (Lee and White 4-in.

tube test at $\left.37^{\circ} \mathrm{C}.\right) \ldots \ldots \ldots \ldots \ldots \ldots$ a trace of fibrin appeared in each tube at about $17 \mathrm{~min}$. One-stage prothrombin time. ........16 sec. (control $14.5 \mathrm{sec}$.) Prothrombin consumption index........100\%

THROMBOPLASTIN GENERATION TEST Substitution tests using the donor's serum or plasma separately showed N slightly abnormal results. When the donor's alumina $\sigma$ plasma and serum together were incubated with platelets $N$ and calcium, thromboplastin generation was grossly abnormal.

PLATELETS Numerous platelets that appeared morpho- 6 logically normal were present in the stained film.

FURTHER TESTS The history and laboratory investigations suggested the possibility of Hageman deficiency. Margolis (1958) found that Hageman factor may be adsorbed onto glass from which it could not be removed by subsequent washing with saline. 
A clean tube was rinsed with a few drops of normal serum and then thoroughly washed six times in isotonic saline. The excess saline was shaken out and the tube placed in a water bath at $37^{\circ} \mathrm{C}$. Miss S. plasma (collected in the proportion of nine parts of blood to one part of $3.8 \%$ sodium citrate), $0.2 \mathrm{ml}$., was added and re-calcified by adding $0 \cdot 1 \mathrm{ml}$. of $\mathrm{M} / 40$ calcium chloride solution. The clotting time of this plasma was $1 \mathrm{~min} .40 \mathrm{sec}$. with a firm clot appearing. A control test in an untreated tube showed only a trace of fibrin $20 \mathrm{~min}$. after re-calcification. It is apparent that the defect in Miss S. blood lies in the absence of Hageman factor.

Investigation showed that the serum of Miss $\mathbf{S}$. was unable to sensitize glass and correct her own plasma clotting time. Her parents had normal plasma clotting times and both could sensitize glass and correct their daughter's clotting deficiency. The defect could also be corrected by contact with glass activated by normal rabbit serum but duck serum was inactive.

STABILITY OF HAGEMAN FACTOR Investigation with the plasma of Miss S., using the principle of adsorption of Hageman factor onto the interior of clean glass tubes followed by washing in saline, showed that a high concentration of Hageman factor dould be demonstrated in dried plasma (prepared from time expired donor blood), dried serum, and fresh deep frozen plasma (used in the treatment of haemophilia). No activity could be detected with human fibrinogen prepared by the method of Kekwick and Mackay.

Hageman factor could not be adsorbed onto siliconecoated glass, was not removed by absorption with aluminium hydroxide for three minutes, and was not inactivated by heating normal serum for 20 minutes at $56^{\circ} \mathrm{C}$. Repeated washing of a sensitized tube with saline failed to remove the factor, but it was easily removed by washing with $\mathrm{N} / 10$ sodium hydroxide solution.

A titration of Hageman factor in a normal serum, using silicone-coated apparatus to prepare the dilutions, showed that a dilution of 1 in 500 of normal serum in saline would sensitize glass and reduce the subsequent plasma clotting time of Miss S. from 20 minutes to 3 minutes 20 seconds with the formation of a good clot. It is apparent that a very high concentration must be present in the original serum.

Two preparations of brain thromboplastin, one human and one rabbit, prepared by the acetone extraction method of Quick would both strongly sensitize glass and clearly contained potent contact factor. No activity, however, could be demonstrated in human saliva.

In a further experiment a single glass tube was sensitized by rinsing with a 1 in 100 dilution of stored normal serum followed by washing six times with isotonic saline. Miss S. plasma, $0 \cdot 2 \mathrm{ml}$., was added and the tube incubated at $37^{\circ} \mathrm{C}$. for four minutes. The plasma was then poured into a second unsensitized clean tube and re-calcified. The initial sensitized tube was washed twice in saline and a second sample of Miss S. plasma added and incubated for four minutes followed again by transference to a second clean tube and re-calcification. This process was repeated four times. The results are shown in Table I. It is clear that the action of Hageman $8^{*}$ factor is catalytic, and that activation will take place in deficient plasma, even though the source of factor is removed before adding calcium.

\section{TABLE I}

CORRECTION OF PLASMA CLOTTING TIME OF HAGEMANDEFICIENT PLASMA USING TWO STAGES

\begin{tabular}{|c|c|c|}
\hline & & Calcium Clotting Time \\
\hline 1 & $\begin{array}{l}\text { Controls: Hageman-deficient } \\
\text { plasma in untreated tube }\end{array}$ & More than $20 \mathrm{~min}$. (poor clot) \\
\hline 2 & $\begin{array}{l}\text { Hageman-deficient plasma in } \\
\text { untreated tube after pre-activation } \\
\text { for } 4 \text { minutes in sensitized tube }\end{array}$ & $3 \mathrm{~min} .35 \mathrm{sec}$. (good clot) \\
\hline & $\begin{array}{l}\text { As } 2 \text { above. Second application } \\
\text { of Hageman-deficient plasma to } \\
\text { same sensitized tube }\end{array}$ & $2 \mathrm{~min} .43 \mathrm{sec} .(\mathrm{good}$ clot $)$ \\
\hline & $\begin{array}{l}\text { As } 2 \text { above. Third application } \\
\text { of Hageman-deficient plasma to } \\
\text { same sensitized tube }\end{array}$ & $3 \mathrm{~min} .10 \mathrm{sec}$ (good clot) \\
\hline & $\begin{array}{l}\text { As } 2 \text { above. Fourth application } \\
\text { of Hageman-deficient plasma to } \\
\text { same sensitized tube }\end{array}$ & $3 \mathrm{~min} .2 \mathrm{sec}$. (good clot) \\
\hline
\end{tabular}

\section{DISCUSSION}

Unless the possibility of Hageman deficiency is kept in mind, individuals who are affected by this abnormality may not be detected. Miss S. donated blood on two occasions without detection in the laboratory and it is probable that on both occasions the laboratory samples of her blood came into contact at some time with a glass surface that was 'clean' but nevertheless sensitized with contact factor from the blood of a previous donor. The experimental evidence shows how potent the contact factor is in normal serum and it is apparent that only the briefest exposure to a sensitized surface is necessary to correct the defect.

The normal serological laboratory procedure of using saline-washed pasteur pipettes for the separation of serum and cells will lead to immediate activation of the clotting mechanism, as indeed must have happened on the first and second occasions that Miss S. donated. It is vital that all tubes, pipettes, etc., used in the investigation of possible cases of Hageman deficiency should be cleaned in strong alkali before use.

The greatly prolonged plasma clotting time followed by correction when the test is repeated in a saline washed tube 'sensitized' with normal human serum enables the nature of the defect to be demonstrated very simply.

\section{REFERENCES}

Biggs, R., Sharp, A. A., Margolis, J., Hardisty, R. M., Stewart, J., and Davidson, W. M. (1958). Brit. J. Haemat., 4, 177.

Margolis, J. (1957). Nature (Lond.), 180, 1464.

- (1958). Ibid, 182, 1102.

Ratnoff, O. D. and Colopy, J. E. (1955). J. clin. Invest., 34, 602.

Soulier, J. P., Wartelle, O., and Ménaché. D. (1958). Rev. frans. Et. clin. biol., 3, 263. 